\title{
Використання методик стратегічного аналізу при проведенні оборонного планування Державної прикордонної служби України
}

\author{
Артем Братко * 1 А; Дмитро Софіян ${ }^{2}$ А; Олег Ковальчук 3 А \\ А Національна академія Державної прикордонної служби України імені Богдана Хмельницького, вул. Шевченка, 46, Хмельницький, 29000, Україна
}

Received: June 1, 2021 | Revised: June 19, 2021 | Accepted: June 30, 2021

DOI: $10.33445 /$ sds.2021.11.3.8

\begin{abstract}
Анотація
Державна прикордонна служба України є складовою сектору безпеки і оборони та зі зміною умов та подальшого розвитку постала необхідність у проведенні огляду стану на основі методики аналізу сильних та слабких сторін, можливостей та загроз (SWOT), що $\epsilon$ обгрунтуванням для визначення основних напрямків розвитку Державної прикордонної служби України. Вихідними даними $є$ існуюча законодавча база, сценарії та ситуації розвитку воєнно-політичної обстановки, функції та обов'язки прикордонного відомства. Методом експертної оцінки визначено важливість основних параметрів та за допомогою SWOT - аналізу в умовах повсякденної діяльності, в умовах ускладнення обстановки та в умовах воєнного характеру, можливостей та загроз, обґрунтовано напрямки подальшого розвитку Державної прикордонної служби України для забезпечення ефективного застосування прикордонного відомства в принципово нових умовах. SWOT - аналіз $€$ адекватним методом для проведення стратегічного аналізу, який надає змогу визначення напрямів розвитку частин та підрозділів Державної прикордонної служби України та обґрунтування їх завдань. Таким чином, проведений аналіз визначає сильні та слабкі сторони прикордонного відомства, можливості та загрози в умовах повсякденної діяльності, в умовах ускладнення обстановки та в умовах воєнного характеру, що в подальшому може бути використаний під час надання пропозицій щодо визначення основних напрямів діяльності та подальшого розвитку Державної прикордонної служби України, а також враховано під час надання пропозицій щодо змісту проєкту Стратегії громадської безпеки та цивільного захисту України.
\end{abstract}

Ключові слова: методика, оборонне-планування, сили та засоби.

\section{Постановка проблеми}

Забезпечення прикордонної безпеки має безумовно важливе значення в контексті загального розвитку нашої держави та реалізації їі національних інтересів.

Державна прикордонна служба України (далі-ДПСУ) продовжує свій розвиток у рамках загальної реформи сектору безпеки і оборони України та забезпечує не лише охорону, а й захист державного кордону.

Відповідно до взятого Україною курсу на євроатлантичну інтеграцію та запровадження кращих європейських практик управління кордонами Урядом схвалено Стратегію інтегрованого управління кордонами на період до 2025 року та план її реалізації на перші три роки. На сьогодні впровадження інтегрованого управління кодонами $€$ одним 3 головних пріоритетів реалізації державної політики у сфері охорони державного кордону.

Крім того, ДПСУ у взаємодії з іншими суб'єктами сектору безпеки і оборони України здійснює комплекс заходів щодо протидії гібридним загрозам найрізноманітнішого характеру. Зокрема, збройна агресія Російської

\footnotetext{
${ }^{1}$ Corresponding author: кандидат військових наук, доцент, доцент кафедри, e-mail: bratkoav84@gmail.com, ORCID: 0000-0001-5503-3318

2 кандидат психологічних наук, професор кафедри, e-mail: dima_sofiyan84@ukr.net, ORCID: 0000-0002-5767-7616

${ }^{3}$ викладач кафедри, e-mail: kanekorcoq3@gmail.com, ORCID: 0000-0001-5777-0442
} 
Федерації проти України, внаслідок якої окуповано невід'ємну частину території України - Автономну Республіку Крим та втрачено контроль над кордоном в окремих районах Донецької та Луганської областей України, поширення тероризму, сепаратизму, наркобізнесу, незаконної торгівлі зброєю і ядерними матеріалами, транскордонної організованої злочинності, нелегальної міграції, торгівлі людьми, кіберзагроз, поширення гострої респіраторної хвороби COVID-19, спричиненої коронавірусом SARSCoV-2, яка набула у світі статусу пандемії та інші, вимагають оперативного, адекватного реагування та вказують на актуальність та необхідність проведення заходів з подальшого розвитку прикордонного відомства. Для оцінювання стану і готовності сил оборони до виконання завдань щодо оборони України, стану їх кадрового, фінансового, матеріальнотехнічного та інших видів забезпечення у поточних і прогнозованих умовах безпекового середовища проводиться оборонний огляд, що надасть можливість в подальшому забезпечити якісне планування на основі спроможностей.

\section{Аналіз останніх досліджень та публікацій}

У наукових працях авторами [1-7] проведено дослідження щодо організації і планування діяльності 3бройних Сил України (далі - ЗСУ) та інших складових сектору безпеки і оборони; проблем розвитку спроможностей сил безпеки та оборони; стратегічного планування на основі спроможностей за підходами управління які орієнтовані на результат; наявного стану та подальшого розвитку системи оборонного планування в ЗСУ.
У монографії [8], яка присвячена оборонному менеджменту, викладені новітні підходи до впровадження у Міністерстві оборони, Збройних Силах України та інших складових сил оборони системного підходу до оборонного менеджменту.

Проте залишається невирішеним актуальне питання щодо імплементації планування на основі спроможностей в діяльність ДПСУ.

\section{Постановка завдання}

Провести аналіз методик стратегічного планування діяльності підрозділів Державної прикордонної служби України, а також визначити стан прикордонного відомства на основі SWOT - аналізу при проведенні оборонного планування.

\section{Виклад основного матеріалу}

Відповідно до Порядку організації та здійснення оборонного планування в Міністерстві оборони України, Збройних Силах України та інших складових сил оборони, затвердженого наказом МО України від 22.12.2020 № 484, оборонне планування здійснюється 3 метою забезпечення обороноздатності держави шляхом визначення пріоритетів і напрямів розвитку сил оборони, їх спроможностей, озброєння та військової техніки, інфраструктури, підготовки військ (сил), а також розроблення відповідних концепцій, програм і планів з урахуванням реальних і потенційних загроз у воєнній сфері та фінансово-економічних можливостей держави.
Процес оборонного планування ДПСУ здійснюється 3 урахуванням основних характеристик та змісту процесу оборонного планування у державах-членах Організації Північноатлантичного договору (далі - НАТО) та вимог законодавства України і передбачає визначення пріоритетів і напрямів розвитку сил оборони, визначення вимог до спроможностей, розподіл спроможностей за складовими сил оборони та визначення завдань розвитку, імплементацію завдань розвитку, оцінку результатів.

Оборонне планування здійснюється із застосуванням методу планування на основі спроможностей, який орієнтований на загрози та спрямований на розвиток спроможностей 
сил оборони на довгострокову перспективу.

Огляд спроможностей за функціональними групами спроможностей в ДПСУ (далі - огляд спроможностей) передбачає визначення (уточнення) переліків наявних та необхідних спроможностей, формування переліку критичних спроможностей, розроблення (уточнення, внесення змін до) Каталогу спроможностей ДПСУ та функціональних груп спроможностей 3 визначенням розподілу відповідальності за їх підтримання та планування розвитку.

Завданнями огляду спроможностей є:

уточнення складу та змісту функціональних груп спроможностей;

уточнення переліку наявних та необхідних спроможностей сил ДПСУ, а також вимог до Hих;

формування переліку критичних спроможностей ДПСУ;

уточнення (формування) Каталогу спроможностей ДПСУ;

оцінка результатів досягнення вимог до спроможностей ДПСУ.

До проведення заходів огляду спроможностей залучаються відповідні структурні підрозділи ДПСУ, наукові установи та наукові підрозділи вищих військових навчальних закладів, військових навчальних підрозділів закладів вищої освіти, а також вітчизняні та іноземні експерти (за згодою).

Огляд спроможностей проводиться під час оборонного огляду або у період між оборонними оглядами.

Під час огляду спроможностей виконуються такі заходи:

аналіз та відбір наявних та необхідних спроможностей ДПСу для їх включення у перелік наявних та необхідних спроможностей складових сил оборони;

формування переліку критичних спроможностей ДПСУ;

перегляд кількості та змісту функціональних груп спроможностей.

Результати проведення огляду спроможностей оформлюються звітом, який затверджує Голова ДПСУ. До звіту додаються:

функціональні групи спроможностей 3 визначенням розподілу відповідальності за їх підтримання та планування розвитку та Каталог спроможностей ДПСу;

переліки необхідних спроможностей для виконання завдань за різними варіантами застосування, розвиток яких потребує планування на середньо- та довгострокову перспективу;

наявних спроможностей, для утримання яких необхідно спланувати відповідний ресурс;

критичних спроможностей, які необхідно формувати;

надлишкових спроможностей, від яких необхідно позбавитись з метою вивільнення ресурсів [9].

Перелік необхідних спроможностей формується на підставі аналізу розроблених імовірних сценаріїв виникнення та розвитку ситуацій воєнного характеру, варіантів застосування ДПсу та переліку завдань за сценаріями. Під час розроблення зазначеного переліку визначаються вимоги та здійснюється опис кожної спроможності. Перелік необхідних спроможностей $\epsilon$ основою планування розвитку складових сил оборони на середньострокову перспективу.

Переліки надлишкових і критичних спроможностей формуються на підставі порівняння необхідних та наявних спроможностей.

3 метою підтримки процесу формування пропозицій для прийняття управлінських рішень застосовуються методики та інструменти стратегічного аналізу, а саме:

метод експертних оцінок Делфі (Delphi Technique);

методика комплексного аналізування (PEST analysis, political, economic, socio-cultural and technological);

методика аналізування сильних та слабких сторін, можливостей та загроз (SWOT; strengths, weaknesses, opportunities and threats analysis);

методика аналізування прогалин (Gap Analysis);

методика профілювання ризиків (Risk Profiling).

Результатом роботи щодо огляду спроможностей $\epsilon$ розроблений Каталог спроможностей сил оборони та Функціональні 
групи спроможностей із визначенням розподілу відповідальності за їх підтримання та планування подальшого розвитку.

Результати огляду спроможностей, у подальшому, використовуються у ході проведення оборонного огляду Міноборони, а також для розроблення проектів стратегій, концепцій, державних програм та інших стратегічних документів, якими визначаються основні напрями і завдання державної політики у сфері оборони [10].

ДПсу $є$ складовою сектору безпеки i оборони та зі зміною умов та подальшого розвитку постала необхідність у проведенні огляду стану на основі методики аналізування сильних та слабких сторін, можливостей та загроз (SWOT).
Проаналізовано сильні та слабкі сторони ДПСУ в умовах повсякденної діяльності, в умовах ускладнення обстановки та в умовах воєнного характеру, а також можливості та загрози у визначених умовах.

Вихідними даними $€$ існуюча законодавча база, сценарії та ситуації розвитку воєннополітичної обстановки, функції та обов'язки. Метою оцінки $€$ визначення напрямків подальшого розвитку ДПСУ.

Методом експертної оцінки визначено важливість сильних (табл. 1) та слабких сторін, а також можливостей (табл. 2) та загроз (табл. 3). Важливість визначена від 1 до 10, де 1 найменш важливе значення, 10 найбільш важливе значення.

Таблиця 1 - Оцінка вмісту сильних сторін в умовах воєнного характеру

\begin{tabular}{|c|c|c|c|c|c|c|c|c|c|c|c|c|}
\hline \multirow{2}{*}{$\begin{array}{c}\text { Сильні сторони в умовах } \\
\text { воєнного характеру }\end{array}$} & 1 & 2 & 3 & 4 & 5 & 6 & 7 & 8 & 9 & 10 & \multirow{2}{|c|}{$\begin{array}{c}\text { Важливість } \\
\text { сильних } \\
\text { сторін }\end{array}$} \\
\hline 1 & 5 & 7 & 7 & 5 & 5 & 6 & 7 & 5 & 5 & 5 & 57 & 0,103 \\
\hline 2 & 10 & 9 & 8 & 10 & 9 & 9 & 8 & 8 & 9 & 10 & 90 & 0,163 \\
\hline 3 & 6 & 5 & 6 & 7 & 7 & 7 & 6 & 7 & 6 & 6 & 63 & 0,114 \\
\hline 4 & 1 & 1 & 2 & 2 & 2 & 3 & 3 & 1 & 1 & 2 & 18 & 0,032 \\
\hline 5 & 9 & 10 & 9 & 9 & 8 & 8 & 10 & 10 & 8 & 9 & 90 & 0,163 \\
\hline 6 & 8 & 8 & 10 & 8 & 10 & 10 & 9 & 9 & 10 & 8 & 90 & 0,163 \\
\hline 7 & 7 & 6 & 5 & 6 & 6 & 5 & 5 & 6 & 7 & 7 & 60 & 0,109 \\
\hline 8 & 4 & 3 & 3 & 1 & 3 & 4 & 1 & 2 & 4 & 1 & 26 & 0,047 \\
\hline 9 & 3 & 2 & 4 & 3 & 4 & 2 & 2 & 4 & 3 & 4 & 31 & 0,056 \\
\hline 10 & 2 & 4 & 1 & 4 & 1 & 1 & 4 & 3 & 2 & 3 & 25 & 0,045 \\
\hline$\Sigma$ & 55 & 55 & 55 & 55 & 55 & 55 & 55 & 55 & 55 & 55 & 550 & 1 \\
\hline
\end{tabular}

Сильні сторони в умовах воєнного характеру:

1. забезпечення ритмічного функціонування контрольних пунктів в'їзду-виїзду та пропуску через адмінмежу осіб і транспортних засобів;

2. участь органів і підрозділів ДПСу у проведенні операції Об'єднаних сил у межах Луганської та Донецької областей;

3. участь підрозділів бойового резерву (прикордонних комендатур швидкого реагування, мобільних прикордонних застав) у спільних діях з іншими складовими сектору безпеки та оборони;

4. забезпечення готовності до взяття під охорону тимчасово неконтрольованої ділянки державного кордону в межах окремих районів
Донецької та Луганської областей після відновлення на них конституційного ладу України;

5. планування та застосування сил і засобів при виникненні кризових ситуацій воєнного характеру на державному кордоні та у відсічі збройної агресії на територію України;

6. охорона і оборона узбережжя Азовського моря в межах Донецької області, українськоросійського кордону в межах Луганської області;

7. забезпечення роботи Оперативної групи ДПСУ при штабі Об'єднаних сил;

8. проведення режимних, контрольних, розвідувальних, оперативно-розшукових заходів у визначених районах; 
9. високо підготовлений та мотивований персонал, який готовий до рішучих дій при виникненні загроз воєнного характеру у чіткій взаємодії із іншими складовими сектору безпеки і оборони;

10. посилення інженерно-технічного облаштування державного кордону на загрозливих напрямках (облаштування вогневих позицій та місця укритя для особового складу у місцях несення служби прикордонних нарядів, розташування бойових модулів (блокпостів), типові опорні пункти, спостережні пости, рокадні та фронтальні дороги, системи відео контролю та інше.

Таблиця 2 - Оцінка можливостей

\begin{tabular}{|c|c|c|c|c|c|c|c|c|c|c|c|c|}
\hline \multirow{2}{*}{ Можливості } & \multicolumn{10}{|c|}{ Експерти } & \multirow{2}{*}{$\Sigma$} & \multirow{2}{*}{$\begin{array}{c}\text { Важливість } \\
\text { можливостей }\end{array}$} \\
\hline & 1 & 2 & 3 & 4 & 5 & 6 & 7 & 8 & 9 & 10 & & \\
\hline 1 & 10 & 9 & 8 & 8 & 8 & 9 & 9 & 10 & 10 & 10 & 91 & 0,165 \\
\hline 2 & 3 & 1 & 4 & 3 & 4 & 4 & 2 & 1 & 4 & 2 & 28 & 0,05 \\
\hline 3 & 2 & 4 & 3 & 4 & 2 & 3 & 3 & 2 & 1 & 3 & 27 & 0,049 \\
\hline 4 & 4 & 2 & 1 & 2 & 3 & 2 & 4 & 3 & 2 & 4 & 27 & 0,049 \\
\hline 5 & 8 & 7 & 10 & 7 & 9 & 10 & 10 & 9 & 7 & 8 & 85 & 0,154 \\
\hline 6 & 6 & 5 & 5 & 9 & 6 & 7 & 6 & 5 & 5 & 5 & 59 & 0,107 \\
\hline 7 & 5 & 6 & 6 & 5 & 5 & 5 & 5 & 4 & 6 & 9 & 56 & 0,101 \\
\hline 8 & 7 & 8 & 9 & 10 & 7 & 8 & 7 & 8 & 9 & 7 & 80 & 0,145 \\
\hline 9 & 9 & 10 & 7 & 6 & 10 & 6 & 8 & 7 & 8 & 6 & 77 & 0,14 \\
\hline 10 & 1 & 3 & 2 & 1 & 1 & 1 & 1 & 6 & 3 & 1 & 20 & 0,036 \\
\hline$\Sigma$ & 55 & 55 & 55 & 55 & 55 & 55 & 55 & 55 & 55 & 55 & 550 & 1 \\
\hline
\end{tabular}

Можливості:

1. спільно з представниками інших органів сектору безпеки і оборони здійснювати заходи щодо відсічі збройної агресії з використанням усіх необхідних сил і засобів, форм і способів збройної боротьби, недопущення ескалації та розповсюдження агресії на суміжні та інші регіони України, завдання агресору поразки (втрат) та примушення його до відмови від подальшого застосування воєнної сили 3 повним відновленням територіальної цілісності і суверенітету України, а також до надання гарантій щодо відшкодування завданих збитків;

2. реалізація заходів 3 оборони та стримування, активного використання переговорних форматів та консолідації міжнародного тиску на Російську Федерацію як гарантії недопущення ескалації конфлікту 3 боку Росії, зменшення напруги та припинення Російською Федерацією збройної агресії;

3. використання всіх наявних механізмів ООН, Ради Європи, ОБСЄ, інших міжнародних організацій для консолідації міжнародної підтримки України у протидії російській агресії, відновленні територіальної цілісності та державного суверенітету України;
4. розвиток відносин зі Сполученими Штатами Америки, Сполученим Королівством Великої Британії і Північної Ірландії, Канадою, Федеративною Республікою Німеччина, Французькою Республікою, сусідніми та іншими державами, а також із міжнародними організаціями для забезпечення міжнародної безпеки та протидії спільним викликам i загрозам, мінімізації їх впливу на Україну;

5. посилення спроможностей Збройних Сил України та інших органів сектору безпеки і оборони;

6. дієва координація та чітка взаємодія органів сектору безпеки і оборони, інших державних органів, територіальних громад, бізнесу, громадянського суспільства і населення;

7. прискорення оборонної та безпекової реформи за нормами, принципами i стандартами НАТО;

8. використання з метою відбитя збройної агресії всіх можливих форм, способів та наявних засобів збройної боротьби, а також завдання ударів агресору на його території 3 дотриманням принципів і норм міжнародного права;

9. можливість застосування воєнної сили 
також для локалізації та ліквідації внутрішнього збройного конфлікту у разі його виникнення. Для ліквідації внутрішнього збройного конфлікту Україна залучатиме Національну гвардію, Збройні Сили, інші військові формування та правоохоронні органи згідно 3 Конституцією України і законами України;

10. Збройні Сили, інші військові формування та правоохоронні органи мають бути також готовими відповідно до рішень РБ ООН та міжнародних договорів України до участі в багатонаціональних операціях 3 підтримання миру і безпеки та гуманітарних операціях під егідою уповноважених на це міжнародних організацій, а також в антитерористичних операціях на території держави та поза їі межами.

\section{Таблиця 3 - Оцінка загроз}

\begin{tabular}{|c|c|c|c|c|c|c|c|c|c|c|c|c|}
\hline \multirow{2}{*}{ Загрози } & \multicolumn{7}{|c|}{ Експерти } & \multirow{2}{*}{ Важливість } \\
\cline { 2 - 14 } & 1 & 2 & 3 & 4 & 5 & 6 & 7 & 8 & 9 & 10 & & загроз \\
\hline 1 & 10 & 9 & 9 & 10 & 10 & 10 & 9 & 9 & 8 & 10 & 94 & 0,17 \\
\hline 2 & 8 & 8 & 10 & 9 & 9 & 9 & 8 & 10 & 10 & 9 & 90 & 0,163 \\
\hline 3 & 9 & 10 & 8 & 8 & 8 & 8 & 10 & 8 & 9 & 8 & 86 & 0,156 \\
\hline 4 & 2 & 1 & 1 & 1 & 2 & 2 & 3 & 2 & 3 & 3 & 20 & 0,036 \\
\hline 5 & 7 & 6 & 6 & 6 & 3 & 4 & 6 & 1 & 7 & 5 & 51 & 0,092 \\
\hline 6 & 3 & 4 & 5 & 5 & 5 & 6 & 4 & 4 & 2 & 2 & 40 & 0,072 \\
\hline 7 & 4 & 3 & 3 & 3 & 4 & 3 & 5 & 5 & 5 & 4 & 39 & 0,07 \\
\hline 8 & 1 & 2 & 2 & 2 & 1 & 1 & 2 & 3 & 4 & 1 & 19 & 0,034 \\
\hline 9 & 6 & 7 & 4 & 4 & 7 & 5 & 1 & 6 & 1 & 6 & 47 & 0,085 \\
\hline 10 & 5 & 5 & 7 & 7 & 6 & 7 & 7 & 7 & 6 & 7 & 64 & 0,116 \\
\hline$\Sigma$ & 55 & 55 & 55 & 55 & 55 & 55 & 55 & 55 & 55 & 55 & 550 & 1 \\
\hline
\end{tabular}

\section{Загрози:}

1. збройна агресія i порушення територіальної цілісності України (тимчасова окупація Росією Автономної Республіки Крим, міста Севастополь та частини території Донецької і Луганської областей), нарощування військової потужності Російської Федерації в рамках цих територій і в безпосередній близькості до українських кордонів, у тому числі потенціальна можливість розгортання тактичної ядерної зброї в Криму;

2. невирішеність питань щодо розмежування державного кордону в акваторії Чорного і Азовського морів, незавершеність договірно-правового оформлення державного кордону України з РФ, Республікою Білорусь та Республікою Молдова;

3. мілітаризація РФ окупованих територій шляхом формування нових військових з'єднань і частин, а також постачання бойовиків, військової техніки та засобів матеріальнотехнічного забезпечення;

4. присутність військового контингенту РФ у придністровському регіоні Республіки
Молдова, який може бути використаний для дестабілізації південних регіонів України;

5. нарощування РФ поблизу державного кордону України угруповання військ 3 потужним ударно-наступальним потенціалом, створення нових, розширення і модернізація наявних баз, об'єктів військової інфраструктури;

6. територіальні претензії РФ до України та посягання на суверенітет України в окремих ії районах;

7. недостатнє фінансування ДПСУ, що призводить до низьких темпів переозброєння на новітні (модернізовані) зразки озброєння та військової техніки;

8. цілеспрямований інформаційний (інформаційно-психологічний) вплив 3 використанням сучасних інформаційних технологій, спрямований на формування міжнародного іміджу України як штучної, нестабільної держави, неспроможної до прогресивного соціально-економічного розвитку, а також на дестабілізацію внутрішньої соціально-політичної обстановки, 
міжетнічних та міжконфесійних відносин в Україні або їі окремих регіонах і місцях компактного проживання національних меншин;

9. блокада із застосуванням воєнної сили морських портів, узбережжя або повітряного простору України, порушення її комунікацій $з$

\section{боку РФ;}

10. збройний конфлікт на державному кордоні України, зокрема прикордонні збройні інциденти (провокації, сутички) з регулярними або нерегулярними силами РФ, незаконними збройними формуваннями тощо.

Таблиця 4-Таблиця визначення важливості сильних сторін та можливостей

\begin{tabular}{|c|c|c|c|c|c|c|c|c|c|c|c|c|c|}
\hline \multirow{2}{*}{ Можливості } & \multicolumn{10}{|c|}{ Сильні сторони в умовах воєнного характеру } & \multirow{2}{*}{$\Sigma$} & \multirow{2}{*}{\begin{tabular}{|c|} 
Важливість \\
можливостей
\end{tabular}} & \multirow{2}{*}{$\begin{array}{c}\sum \mathrm{x} \\
\text { важливість }\end{array}$} \\
\hline & 1 & 2 & 3 & 4 & 5 & 6 & 7 & 8 & 9 & 10 & & & \\
\hline 1 & 0 & 3 & 3 & 2 & 2 & 2 & 3 & 2 & 3 & 3 & 23 & 0,165 & 3,795 \\
\hline 2 & 1 & 3 & 3 & 2 & 1 & 1 & 2 & 1 & 0 & 1 & 15 & 0,05 & 0,75 \\
\hline 3 & 1 & 2 & 1 & 1 & 1 & 1 & 2 & 2 & 0 & 2 & 13 & 0,049 & 0,637 \\
\hline 4 & 1 & 2 & 1 & 1 & 1 & 1 & 2 & 2 & 0 & 2 & 13 & 0,049 & 0,637 \\
\hline 5 & 3 & 3 & 3 & 3 & 3 & 3 & 3 & 3 & 3 & 3 & 30 & 0,154 & 4,62 \\
\hline 6 & 2 & 3 & 3 & 3 & 3 & 3 & 3 & 1 & 2 & 1 & 24 & 0,107 & 2,568 \\
\hline 7 & 2 & 3 & 3 & 3 & 3 & 3 & 3 & 2 & 2 & 1 & 25 & 0,101 & 2,525 \\
\hline 8 & 1 & 3 & 3 & 3 & 3 & 3 & 3 & 2 & 1 & 1 & 23 & 0,145 & 3,335 \\
\hline 9 & 0 & 3 & 3 & 3 & 3 & 1 & 3 & 3 & 2 & 2 & 23 & 0,14 & 3,22 \\
\hline 10 & 0 & 1 & 1 & 3 & 3 & 1 & 1 & 1 & 1 & 0 & 12 & 0,036 & 0,432 \\
\hline$\Sigma$ & 11 & 26 & 24 & 24 & 23 & 19 & 25 & 19 & 14 & 16 & $\sum 402$ & 1 & 22,516 \\
\hline $\begin{array}{c}\text { Важливість } \\
\text { сильних сторін }\end{array}$ & & 167 & 0,114 & 0,032 & 0,163 & 0,163 & 0,109 & 0,047 & 0,056 & 60,045 & 1 & & \\
\hline $\begin{array}{l}\sum \text { х важливість } \\
\text { сильних сторін }\end{array}$ & 1,1 & $2=$ & 2,736 & 0,76 & 3,74 & 3,09 & 2,725 & 0,893 & 0,784 & 40,72 & 20,843 & & 43,359 \\
\hline
\end{tabular}

Таблиця 5 - Таблиця визначення важливості сильних сторін та загроз

\begin{tabular}{|c|c|c|c|c|c|c|c|c|c|c|c|c|c|}
\hline \multirow{2}{*}{ Загрози } & \multicolumn{10}{|c|}{ Сильні сторони в умовах воєнного характеру } & \multirow{2}{*}{$\Sigma$} & \multirow{2}{*}{\begin{tabular}{|c|} 
Важливість \\
загроз
\end{tabular}} & \multirow{2}{*}{\begin{tabular}{|l}
$\sum x$ \\
загрози
\end{tabular}} \\
\hline & 1 & 2 & 3 & 4 & 5 & 6 & \begin{tabular}{|l|}
7 \\
\end{tabular} & 8 & 9 & 10 & & & \\
\hline 1 & 1 & 3 & 3 & 3 & 3 & 3 & 3 & 3 & 2 & 2 & 26 & \begin{tabular}{l|}
0,17 \\
\end{tabular} & 4,42 \\
\hline 2 & 0 & 3 & 3 & 3 & 3 & 3 & 3 & 1 & 1 & 1 & 21 & 0,163 & 3,423 \\
\hline 3 & 2 & 2 & 3 & 2 & 3 & 2 & 3 & 2 & 1 & 2 & 22 & 0,156 & 3,432 \\
\hline 4 & 0 & 1 & 1 & 1 & 3 & 0 & 1 & 3 & 1 & 3 & 14 & 0,036 & 0,504 \\
\hline 5 & 2 & 2 & 1 & 2 & 2 & 3 & 3 & 3 & 1 & 2 & 21 & 0,092 & 1,932 \\
\hline 6 & 1 & 2 & 2 & 1 & 3 & 3 & 3 & 3 & 1 & 3 & 22 & 0,072 & 1,584 \\
\hline 7 & 2 & 2 & 2 & 1 & 2 & 2 & 1 & 1 & 1 & 3 & 17 & 0,07 & 1,19 \\
\hline 8 & 3 & 1 & 1 & 1 & 3 & 2 & 3 & 3 & 1 & 2 & 20 & 0,034 & 0,68 \\
\hline 9 & 0 & 2 & 3 & 2 & 3 & 3 & 3 & 3 & 2 & 2 & 23 & 0,085 & 1,955 \\
\hline 10 & 3 & 3 & 3 & 3 & 3 & 3 & 3 & 3 & 1 & 2 & 27 & 0,116 & 3,132 \\
\hline$\Sigma$ & 14 & 21 & 22 & 19 & 28 & 24 & 26 & 25 & 12 & 22 & $\sum 426$ & 1 & 22,252 \\
\hline $\begin{array}{c}\text { Важливість } \\
\text { сильних сторін }\end{array}$ & 0,103 & 0,163 & 0,114 & 40,032 & 20,163 & 30,163 & $0,109 c$ & 0,047 & 0,056 & 0,045 & 1 & & \\
\hline $\begin{array}{l}\sum \mathrm{x} \text { важливість } \\
\text { сильних сторін }\end{array}$ & 1,442 & 3,423 & 2,508 & 30,608 & 84,564 & 43,912 & 2,834 & 1,175 & 0,672 & 0,99 & 22,128 & & 44,38 \\
\hline
\end{tabular}

Узагальнені дані сильних та слабких сторін ДПСу в умовах повсякденної діяльності, в умовах ускладнення обстановки та в умовах воєнного характеру, можливостей та загроз відображені в табл. 6 
Таблиця 6 - Таблиця сильних та слабких сторін, можливостей та загроз

\begin{tabular}{|l|c|c|c|c|c|c|}
\hline \multirow{2}{*}{ Зв'язок } & \multicolumn{2}{|c|}{$\begin{array}{c}\text { Умови повсякденної } \\
\text { діяльності }\end{array}$} & $\begin{array}{c}\text { Умови ускладнення } \\
\text { обстановки }\end{array}$ & \multicolumn{2}{c|}{$\begin{array}{c}\text { Умови воєнного } \\
\text { характеру }\end{array}$} \\
\cline { 2 - 7 } & $\begin{array}{c}\text { Кількість } \\
\text { зв'язків }\end{array}$ & Величини & $\begin{array}{c}\text { Кількість } \\
\text { зв'язків }\end{array}$ & Величини & $\begin{array}{c}\text { Кількість } \\
\text { зв'язків }\end{array}$ & Величини \\
\hline Сильні сторони - можливості & 279 & 27,8 & 348 & 37,6 & 402 & 43,4 \\
\hline Слабкі сторони - можливості & 398 & 39,9 & 420 & 42,5 & 452 & 47,3 \\
\hline Сильні сторони - загрози & 304 & 30,9 & 280 & 30,4 & 426 & 44,4 \\
\hline Слабкі сторони - загрози & 362 & 36,8 & 366 & 38,3 & 412 & 41,7 \\
\hline
\end{tabular}

\section{Висновки}

Таким чином за допомогою SWOT - аналізу проведено оцінку сильних та слабких сторін ДПсу в умовах повсякденної діяльності, в умовах ускладнення обстановки та в умовах воєнного характеру, можливостей та загроз і обґрунтовано напрямки подальшого розвитку Дпсу для забезпечення ефективного застосування прикордонного відомства в принципово нових умовах. Аналіз $є$ науково- методичною основою, який в подальшому може бути використаний під час надання пропозицій щодо визначення основних напрямів діяльності та подальшого розвитку Державної прикордонної служби України, а також враховано під час надання пропозицій щодо змісту проєкту Стратегії громадської безпеки та цивільного захисту України.

\section{Список використаних джерел}

1. Руснак І.С. та ін. Оборонне планування на основі спроможностей: особливості та перспективи впровадження. Наука $i$ оборона. 2017. № 2. C. 3-10. DOI: 10.33099/2618-1614-2017-0-2-3-10.

2. Горбулін В.П. Розвиток оборонного планування як складової національної системи планування у сфері безпеки і оборони за умов наближення до процедур та стандартів НАТО : аналітична записка. Київ : НІСД, 2017. 17 с.

3. Буняк О.В., Бондарь Р.Г., Романюк І.М. Проблеми розвитку спроможностей сил оборони. Проблеми формування ефективної політики, системи планування $і$ управління ресурсами в секторі оборони з використанням сучасних євроатлантичних підходів : матеріали Міжнар. наук.-практ. конф., 24 бер. 2017 р. Київ : НУОУ, 2017. С. 16-19.

4. Романченко І. С., Богданович Ю. В., Дєнєжкін М. М., Крикун П. М. Стан і перспективи розвитку системи оборонного планування в Збройних Силах України. Наука і оборона. 2017. № 1. С. 2530.

5. Хоффман Ф.Г. Большая стратегия: основне соображения. Орбис. 2014. № 58 (4). С. 472-485. DOI: 10.1016/j.orbis.2014.08.002.

6. Development and Implementation of the Target Function in the Decision-Making Process in the System of Providing the Military Security of the State / V.O. Kosevtsov et al. Eastern-European Journal of Enterprise Technologies. 2020. Vol. 5, №. 3. P. 17-23. DOI: 10.15587/1729-4061.2020.215128.

7. National Resilienceas a Determinant of National Security of Ukraine / S. Bondarenko et al. Journal of Optimization in Industrial Engineering. 2021. Vol. 14, №. 1. P. 111-117. DOI: 10.22094/JOIE.2020.677837.

8. Оборонна реформа: системний підхід до оборонного менеджменту : монографія / А. Павліковський, В. Фролов, Ф. Саганюк та ін.; за заг. ред. д-ра військ. наук А. Сиротенка. Київ : НУОУ, 2020. 274 с

9. Братко А. В, Мисик А. Б. Роль Державної прикордонної служби України в системі воєнної безпеки в умовах гібридної війни. Честь і закон. 2021. № 1 (76). C. 5-10. DOI: 10.33405/2078-7480/2021/1/76/229210

10. Оборонний огляд: український вимір 2014-2018: монографія / Ф. Саганюк, А. Павліковський, П. Щипанський, 
В. Павленко та ін.; за заг. ред. д. військ. н., України, НУОУ, 2019. 196 с.

проф. І. Руснака. Київ: МО та ГШ ЗС

\title{
Использование методик стратегического анализа при проведении оборонного планирования Государственной пограничной службы Украины
}

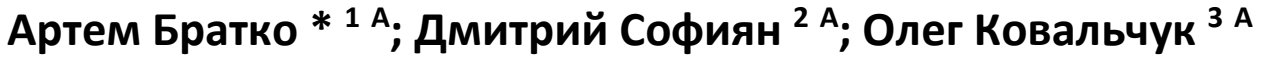 \\ ${ }^{1}$ Corresponding author: кандидат военных наук, доцент, доцент кафедры, e-mail: bratkoav84@gmail.com, ORCID: 0000-0001-5503-3318 \\ 2 кандидат психологических наук, профессор кафедры, e-mail: dima_sofiyan84@ukr.net, ORCID: 0000-0002-5767-7616 \\ 3 преподаватель кафедры, e-mail: kanekorcoq3@gmail.com, ORCID: 0000-0001-5777-0442 \\ АНациональная академия Государственной пограничной службы Украины имени Богдана Хмельницкого, ул. Шевченко, 46, Хмельницкий, Украина
}

\begin{abstract}
Аннотация
Государственная пограничная служба Украины является составной сектора безопасности и обороны и с изменением условий и дальнейшего развития возникла необходимость в проведении осмотра состояния на основе методики анализа сильных и слабых сторон, возможностей и угроз (SWOT), что является обоснованием для определения основных направлений развития Государственной пограничной службы Украина. Исходными данными являются существующая законодательная база, сценарии и ситуации развития военно-политической обстановки, функции и обязанности пограничного ведомства. Методом экспертной оценки определены важность основных параметров и с помощью SWOT - анализа в условиях повседневной деятельности, в условиях осложнения обстановки и в условиях военного характера, возможностей и угроз, обоснованы направления дальнейшего развития Государственной пограничной службы Украины для обеспечения эффективного применения пограничного ведомства в принципиально новых условиях. SWOT - анализ является адекватным методом для проведения стратегического анализа, который дает возможность определения направлений развития частей и подразделений Государственной пограничной службы Украины и обоснование их задач. Таким образом, проведенный анализ определяет сильные и слабые стороны пограничного ведомства, возможности и угрозы в условиях повседневной деятельности, в условиях осложнения обстановки и в условиях военного характера, в дальнейшем может быть использован во время предоставления предложений по определению основных направлений деятельности и дальнейшего развития Государственной пограничной службы Украины, а также учтено при предоставлении предложений по содержанию проекту Стратегии общественной безопасности и гражданской защиты Украины.
\end{abstract}

Ключевые слова: методика, оборонное-планирование, силы и средства.

\section{Use of methods of the strategic analysis in conducting defense planning of the State Border Guard Service of Ukraine}

\author{
Artem Bratko *A 1; Dmytro Sofijan A ${ }^{\text {; }}$ Oleg Kovalchuk ${ }^{\text {A } 3}$ \\ * Corresponding author: ${ }^{1}$ PhD in Military Sciences, Associate Professor, e-mail: bratkoav84@gmail.com, ORCID: 0000-0001-5503-3318 \\ 2 PhD in Psychology, e-mail: dima_sofiyan84@ukr.net, ORCID: 0000-0002-5767-7616 \\ 3 teachers of the department, e-mail: kanekorcoq3@gmail.com, ORCID: 0000-0001-5777-0442 \\ A National Academy of the State Border Guard Service of Ukraine named after Bohdan Khmelnitskyi, Ukraine
}

\begin{abstract}
The State Border Guard Service of Ukraine is a component of the security and defense sector and with changing conditions and further development there is a need to conduct a review of
\end{abstract}


the situation based on the analysis of strengths, weaknesses, opportunities and threats (SWOT), which is the basis for determining the main directions of the State Border Guard Service. Of Ukraine. The initial data are the existing legal framework, scenarios and situations of development of the military-political situation, functions and responsibilities of the border agency. The importance of the main parameters was determined by the method of expert assessment and with the help of SWOT analysis in the conditions of daily activity, in the conditions of complication of the situation and in the conditions of military character, opportunities and threats, the directions of further development of the State Border Guard Service of Ukraine were substantiated. SWOT - analysis is an adequate method for conducting strategic analysis, which allows to determine the directions of development of units and subdivisions of the State Border Guard Service of Ukraine and substantiation of their tasks. Thus, the analysis identifies the strengths and weaknesses of the border agency, opportunities and threats in the day-to-day, in a difficult situation and in a military nature, which can be further used in providing proposals to determine the main activities and further development of the State. Border Guard Service of Ukraine, as well as taken into account when submitting proposals on the content of the draft Strategy of Public Safety and Civil Protection of Ukraine.

Key words: methodology, defense planning, forces and means.

\section{References}

1. Rusnak I. S. ta in. (2017) Oboronne planuvannya na osnovi spromozhnostey: osoblyvosti ta perspektyvy vprovadzhennya. Nauka i oborona. № 2. S. 3-10. DOI: 10.33099/2618-1614-2017-0-2-3-10.

2. Horbulin V. P. Rozvytok oboronnoho planuvannya yak skladovoyi natsional'noyi systemy planuvannya u sferi bezpeky i oborony za umov nablyzhennya do protsedur ta standartiv NATO: analitychna zapyska. Kyiv: NISD, 2017. $17 \mathrm{~s}$.

3. Bunyak O. V., Bondar' R. H., Romanyuk I. M. Problemy rozvytku spromozhnostey syl oborony. Problemy formuvannya efektyvnoyi polityky, systemy planuvannya i upravlinnya resursamy $v$ sektori oborony $z$ vykorystannyam suchasnykh yevroatlantychnykh pidkhodiv : materialy Mizhnar. nauk.-prakt. konf., 24 ber. 2017 r. Kyiv: NUOU, 2017. S. 16-19.

4. Romanchenko I. S., Bohdanovych YU. V., Dyenyezhkin M. M., Krykun P. M. (2017) Stan i perspektyvy rozvytku systemy oboronnoho planuvannya $v$ Zbroynykh Sylakh Ukrayiny. Nauka i oborona. 2017. № 1. S. 25-30.

5. Khoffman F. H. Bol'shaya stratehyya: osnovne soobrazhenyya. Orbys. 2014. № 58 (4). S. 472-485. DOI: 10.1016/j.orbis.2014.08.002.
6. Kosevtsov V.O. et al. (2020) Development and Implementation of the Target Function in the Decision-Making Process in the System of Providing the Military Security of the State. Eastern-European Journal of Enterprise Technologies. Vol. 5, №. 3. P. 17-23. DOI: 10.15587/1729-4061.2020.215128.

7. Bondarenko S. et al. (2021) National Resilienceas a Determinant of National Security of Ukraine. Journal of Optimization in Industrial Engineering. Vol. 14, №. 1. P. 111-117. DOI: 10.22094/JOIE.2020.677837.

8. Oboronna reforma: systemnyy pidkhid do oboronnoho menedzhmentu : monohrafiya / A. Pavlikovs'kyy, V. Frolov, F. Sahanyuk ta in.; za zah. red. d-ra viys'k. nauk A. Syrotenka. Kyiv : NUOU, 2020. 274 s.

9. Bratko A. V, Mysyk A. B. (2021) Rol' Derzhavnoyi prykordonnoyi sluzhby Ukrayiny v systemi voyennoyi bezpeky $v$ umovakh hibrydnoyi viyny. Chest' i zakon. № 1 (76). S. 5-10. DOI: 10.33405/20787480/2021/1/76/229210

10. Oboronnyy ohlyad: ukrayins'kyy vymir 2014-2018: monohrafiya / F. Sahanyuk, A. Pavlikovs'kyy, P. Shchypans'kyy, V. Pavlenko ta in.; za zah. red. d. viys'k. n., prof. I. Rusnaka. Kyiv: MO ta HSH ZS Ukrayiny, NUOU, 2019. $196 \mathrm{~s}$. 